\title{
Participatory Budgeting: A Case Study of Provincial Administrative Organization
}

\author{
Darunee Pumkaew ${ }^{1}$, Banjerd Singkaneti ${ }^{2}$ \\ Faculty of Political Science, Ubon Ratchathani University, Thailand \\ Faculty of Law, National Institute of Development Administration, Thailand \\ Email: ${ }^{1}$ pk_darunee@ hotmail.com, ${ }^{2}$ bsingkaneti@gmail.com
}

\begin{abstract}
The objective of this paper is to study the budgeting process of Provincial Administrative Organizations in Thailand and to examine the limits to public participation in the budgeting process. The paper also offers recommendations on how to increase public participation in the budgeting process. The study uses qualitative methods, studying documents related to budgeting process such as laws and regulations, in addition to using in-depth interviews with administrators and staff at Provincial Administrative Organizations. The research shows that the current budgeting process of Provincial Administrative Organizations limits public participation. Participation is limited to local development plan making, which only acts as a guideline, and is nonbinding. The final decision makers of the annual budget are the administrators of the Provincial Administrative Organizations and Provincial Administrative Organizations Council. Therefore, to increase public participation in budgetary decisions, the paper recommends that the central government enacts legislation that creates mechanisms that allows people to participate in budget allocation decisions. In this regard, the nature or type of participatory may that a form suitable to each area. Examples include direct decisions about public matters or political issues or in the form of a third-party intermediary intermediation.
\end{abstract}

Keywords

Participatory Budgeting; Local Government; Province Administrative Organization

\section{Introduction}

Limited resources can be optimized to make the policymaking process more efficient. Budgets are a vital component for effective resource allocation and utilization that requires public participation. Constituents are key stakeholders, often better informed about what crucial and needed. Their engagement in the decision-making process can maximize their benefits. Studies suggest that the scarcity of financial resources is closely aligned with the lack of people's participation in budgeting process. Yet, according to Justice and Dülger[1], people rarely play a role in the state's budgeting procedures.

In Thailand, localities have two concurrent budgeting types: function-based budgeting and area-based budgeting. Function-based budgeting is the allocation of financial resources by ministries in response to national policies and the country's development. The second type, area-based allocation, distributes the budget to localities based on their needs, specific problems they might face and development goals. The second budgeting type requires public participation during budget planning, allocation and auditing to ensure that the allocated budget meets local needs.

However, local budgeting procedures rarely empower people's participation, making it challenging for constituents to raise problems, make decisions, or clarification and inspection [2]. Participatory budgeting is the channel for people's participation in budget allocation as introduced by the Local
Administrative Reformation Committee and National Reform Council [2]. Peoples' concerns and priorities can be heard through the participatory process, which is a form of direct participation that ensures constituents are involved in budgetary decisions. This approach is a meant to result in an effective budget that reflects people's needs.

This study explores the budgeting procedure and people's participation in local budgeting. The Provincial Administrative Organization (PAO) is the case study owing to its duty to provide public services over an entire provincial area. They earn higher annual budgets than local administrative organizations (LAOs), which cover smaller areas within provinces. All 76 provincial administrative organizations follow the same budgeting procedures by law.

\section{Research Objectives}

The objectives of this research article is to explore the budgeting procedure and people's participation in budgeting procedure in Provincial Administrative Organization (PAO).

\section{Research Methods}

\section{Research Design}

Two methods are used in this qualitative study. First, the study uses documentary research of relevant documents, such as laws and regulations. Second, the study uses in-depth interview with executives and staff members of various PAOs, including Director of the Finance Division, Chief Administrator of the PAO, 
Director of the Planning and Budgeting Division and the Chief of the Budgeting Unit. Data was collected in 2019 Fiscal Year.

\section{Conceptual framework}

Participatory budgeting is a method by which constituents can participate in the decision-making process on how to use a new budget. Through this process, people learn about the government's performance, their decision-making process, discussion and power in public resource allocation[3]. Participatory budgeting is a decision-making process that begins with cogitation and negotiation to allocate or distribute public resources. With participatory budgeting, constituents are directly involved in the decision-making process on how to utilize such resources [4]. This type of budgeting process contains five steps. First, it needs to design the process for constituent participation in budgeting. Second, participants brainstorm ideas from constituent on what they need or which issues to be fixed. Third, project proposals are developed and prioritized. Fourth, is constituent voting. People select their most wanted projects to for budget support. And fifth, the final budget is allocated to the highest voted projects. Participation allows effective resource use, transparency and good governance. Expectedly, this budgeting form would diminish the state's low performance, patronage relations and corruption.

\section{Results}

1. The documentary analysis of the laws and regulations reveals that Thailand only allows for participatory budgeting during the initial part of the budget.

2. Laws and regulations regarding PAO's budgeting mentioned are: (1) Plan and Procedure for Decentralization of the Local Administrative Organization Act, B.E. 2542; (2) Provincial Administrative Organization Act, B.E. 2540 and the Amendment; (3) Ministry of Interior Regulation on Local Government Budgeting, B.E. 2541, the Second Amendment, B.E. 2543 and the Third Amendment, B.E. 2543 and; (4) Ministry of Interior Regulation on Formulation of Local Development Plan of Local Administrative Organization, B.E. 2548 and the Amendment.

All in all, these laws and regulations show that there are two main steps to the PAO's budgeting procedure. The first step is the formulation of the development plan, and drafting the development plan. Second is budgeting of PAOs composed of drafting the provisions of annual expenditure budget, budget approval and announcement respectively.

a. Formulating development plan
The plan guides the direction of the local development. In addition, the plan must be accompanied with a budget. The local government organization must develop a local development plan while following the local development plan as a guideline for budgeting.

PAO chooses the authorities taking charge of formulating the development plan in two types of committee; local development committee and local development promotion committees(Figure 1).

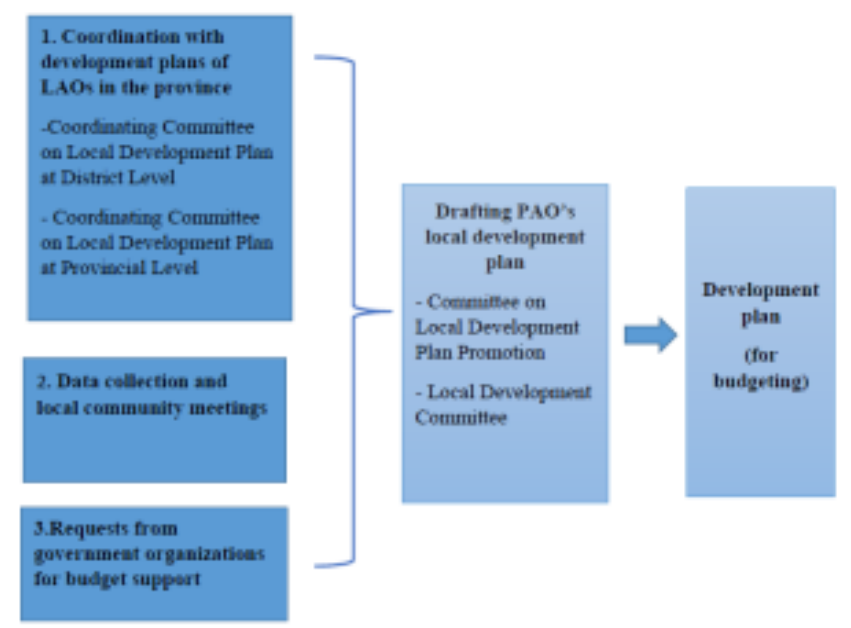

\section{Fig.1 Process for formulating the local development plan of PAO}

Projects included in the PAO's development plan come from three channels; the PAO's data collection and local community meetings, requests from government organizations for budget support and coordination with development plans of local administrative organizations in the province. 1)Data collection and local community meetings, PAO can initiate projects using data and information from local community meetings. They are forums for local people within PAOs' jurisdiction to share ideas and concerns about development issues, make collective decision on project and take action on issues in accordance with the designated functions of PAOs. The obtained information helps the Committee on Local Development Plan Promotion analyze the feasibility and legal matters of projects. Then, the Division of Public Works conducts the survey and nails down the needs and subsequent quotes of the projects. These projects will be included in the PAO's development plan. 2)Requests from others government organizations for budget support. As per Ministry of Interior Regulation on Grant for Local Administrative Organization, B.E. 2559, local administrative organizations shall prepare grant budget as requested by government organizations to perform designated functions. 3)Coordination with development plans of local administrative organizations in the province. There are two types; Coordinating Committee on Local Development Plan at District Level, and 
Coordinating Committee on Local Development Plan at Provincial Level.

For the Coordinating Committee on Local Development Plan at District Level, upon receipt of these detailed development projects from municipalities and SAOs, the Coordinating Committee at the district level carries out a review of the projects and prioritizes them. The committee reviews the projects based on the following principle (1) development projects are within the jurisdictions of at least two LAOs are beneficial to both as agreed; (2) large-scale development projects with large budgets that are beyond the capacity of LAOs and impacts on the province's development; (3) development projects that require advanced technology or experts as supervisors and advisors; (4) development projects with potential large-scale impacts on natural resources, the environment, social-geography, culture, tradition and lifestyle, and such impacts go beyond the jurisdiction of LAOs; (5) prevention of natural disasters such as floods, storms, wildfires, and which require joint efforts among LAOs. These also cover man-made threats to life and property, insurgency, deforestation, environmental destruction and druginduced incidents; (6) actions under as assigned by law and; (7) other cases as necessary. Following the review and prioritization of proposed projects, the Coordinating Committee at District Level submits the list of projects to the Coordinating Committee at Provincial Level.

The Coordinating Committee on Local Development Plan at Provincial Level is assigned to set the coordinating framework grounded on the development strategy of LAOs in the province, the provincial and national development strategy and submit the framework to LAOs and the Coordinating Committee at District Level, provide opinions and recommendations on each LAO's development plans and how well these plans reflect the development strategy of LAOs in the province. This committee includes the opinions of the Coordinating Committee at the District Level and approves LAOs' development projects in the province as in the list of LAOs' development projects. PAO then includes the listed projects in PAO's development plan and inspects the development projects of municipalities and SAOs in order to avoid overlap between the projects in PAO's development plan and considers projects exceeding the capacity of PAO or important projects beyond PAO's designated functions. The projects should go with the development strategy of LAOs in the province and be in the "List of projects for budget support from the Integrated Provincial Executive Committee". The list is similar to the LAO's list of coordinating projects.

\section{b. Drafting the local development plan}

The Committee on Local Development Plan Promotion collects data on development issues and projects of municipalities and SAOs to be reviewed by the Provincial Coordinating Committee. In addition, the Promotion Committee also analyzes information from local community meetings and projects, then drafts PAO's local development plan and submits it to the Local Development Committee. The draft is prescribed in Clause 10 in Ministry of Interior Regulation on Formulation of Local Development Plan, B.E. 2548 and the Amendment. It says that the provincial administrative organization, municipalities, sub-district administrative organizations, Pattaya City and other local administrative organizations provided by law shall include issues concerning villages' or communities' development plans that exceed their capacity. If they still exceed the capacity of municipalities, sub-district administrative organizations, Pattaya City and other local administrative organizations provided by law, these issues shall be submitted to the provincial administrative organization to include in its development plan according to the designed functions.

After completing the drafted development plan, the Local Development Committee undertakes the review of the draft and submits to local executives. The Committee examines the PAOs' legal duties, mission, development strategy of the country, province group and provinces, the policy framework for the development of LAOs in the province, policies of local executives and the community plan to determine the validity of the plan. The following responsibilities belong to this Committee:

- Planning local development is done on the basis of: (1) PAO's functions; (2) mission transfer according to the Determining Plans and Process of Decentralization to Local Administrative Organization Act; (3) development strategy for the country, province group and provinces; (4) guidelines to LAO development in the province; (5) executive's policies and; (6) community plan. Finally, the recommendations are provided to the development plan and solutions to problems.

- Reviewing the drafted plan and its implementation.

- Approving the drafted provisions.

- Monitoring and evaluating the development plan.

- Appointing advisors or a working group as appropriate.

Following the approval by the committee, the local development plan is officially announced for budgeting later on. 


\section{c. Budgeting of Provincial Administrative Organization}

According to the Ministerial Regulation on Local Government Budgeting, B.E. 2541, and the Amendment, Chapter 3 identifies the budgetary procedures.

"Clause 22 Provincial Administrative Organization shall employ its development plan as a guideline to budgeting. Director of the organization shall prepare the estimated revenue and expenditure. Chief of Finance Division shall gather financial reports and statistics from all units in order to calculate the budget and submit to the budget officer.

Clause 23 The budget officer shall initially examine, analyze and revise the budget and submit to the local executives.

Upon the local executives' approval of budgeting for the annual budget, the budget officer shall gather and draft the expenditure budget and resubmit to the local executives in order that the executives can submit to the Local Council by August 15.

Clause 24 In case the local executives agree not to submit the drafted annual expenditure budget to the Local Council within the prescribed time, the local executives shall submit to the Local Council for approval and report to the Governor. As to sub-district administrative organizations, they shall report to the District Chief or Deputy District Chief who is the Chief of Minor District. Clause 25 The Local Council's approval to the drafted expenditure budget and the authorized person's approval to the drafted expenditure budget shall be in accordance with law, regulation and principle of each type of local administrative organization".

The procedure for drafting the annual expenditure budget and budget approval is the internal system of PAO. There are two jobs in this step, namely drafting the provisions of annual expenditure budget, and budget approval. In the drafting process of the annual expenditure budget (Figure 2), there are concerned authorities, namely, the Chief Executive of PAO, Chief Administrator of PAO, government organizations including units, divisions and bureaus under PAO.

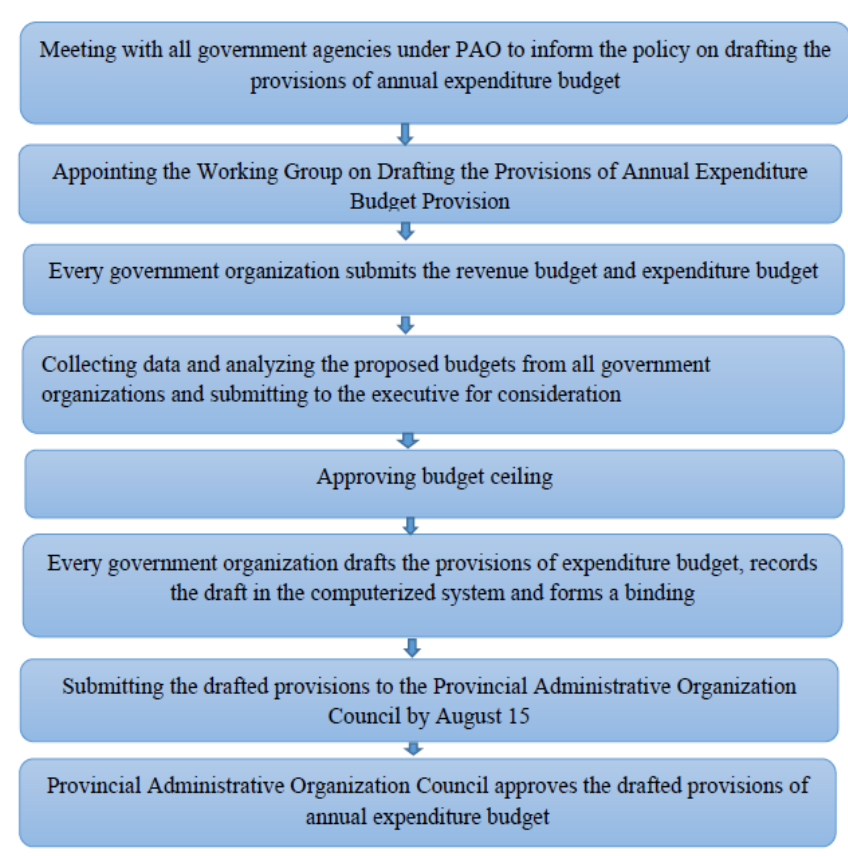

Fig. 2 Steps to draft the provisions of the annual
expenditure budget

For budget approval, upon completion of the drafted provisions, they are submitted to the Provincial Administrative Organization Council for approval. Public participation is absent in this process, but executives and council members.

3. Budget procedure of Provincial Administrative Organization and people's participation, participatory budgeting is a tool contributing towards effectiveness of budgeting. Opening the budgeting process to the public helps determine if investment and development needs are being met in specific localities. Through this channel, people participate in resource allocation, public policy prioritization and inspection of public expenditure.

The findings show that public participation only takes place during the initial stages of formulating the local development plan. Constituents can participate through committees and local community meetings. Constituents are part of the Committee on Local Development Plan Promotion, which requires three representatives from local communities. Together they draft the local development plan as required by the Local Development Committee and submit the draft to the Committee. Local communities are also represented on the Local Development Committee, which requires three to six local representatives.

However, there are no constituent representatives in Coordinating Committee on Local Development Plan at District Level, and Coordinating Committee on Local Development Plan at Provincial Level. The composition of the Coordinating Committee on Local Development Plan at District Level includes local executives of each district, members of the Provincial 
Administrative Organization Council from every district, the Chief of District Office, every Chief Administrator of LAOs from every district, one civil servant from PAO assigned by the Chief Executive of the PAO, one Deputy District Chief assigned by District Chief, Chief Administrator of LAO as Member and Secretary selected by Chair of the Coordinating Committee and, two civil servants or municipal officers or sub-district officers as the Assistant to Secretary selected by the Secretary. Representatives from the local communities are not included.

Meanwhile, the Committee at the provincial level is chaired by the Chief Executive of the PAO. Committee members include the Deputy Chief Executive of PAO responsible for development planning, the Chair of Coordinating Committee at District Level of all districts, the Secretary of Coordinating Committee at District Level of all districts, the Chief of Provincial Office for Local Administration, the Chief of the Provincial Office, the Chief of Provincial Public Works and Town Planning, members (not over five persons) of the PAO Council elected among themselves, the Chairman or representative of Provincial Chamber of Commerce; Chair or representative of Federation of Thai Industries in the province, the Chief Administrator of the PAO, the Chief of Provincial Development Strategy Unit, Provincial Office, the Chief of Local Administration Unit, Provincial Office for Local Administration, civil servants from the PAO or municipal officers or subdistrict officers (not over three persons) responsible for local development plan as Assistant to Secretary. Again, members of local communities are not represented.

Local community meetings function a bit different. According to the Ministry of Interior, Urgent Note No. 0810/2/0600 dated January 29, 2016, local community meetings organized by PAO can vary in their composition and purpose. If PAO organizes local community meetings within the jurisdictions of subdistrict administrative organizations (SAOs), subdistrict municipalities, city municipalities and town municipalities, such meetings process shall be organized the same as these organizations do. As for local community meetings at the district level, they are meetings of individuals or households in all villages, communities and sub-districts within the district's jurisdiction. At the provincial level, local community meetings gather individuals or households in all villages, communities, sub-districts and districts within the province's jurisdiction. Local community meetings at district level must take place prior to the provincial meetings. However, if PAO needs further detailed and clarified information concerning development plans, it may organize meetings at the village, community and sub-district levels. With regards to the public participation in meetings at district and provincial levels, their proportion is determined by Chief Executive of PAO in collaboration with every Deputy Chief Executive of PAOs, Chief Administrator of PAO and Chief of Administrative Unit of PAO equivalent to Chief of Office, Director of Division and Deputy Chief Administrator of PAO (if any).

Moreover, the proportion of public participation in local community meetings is small. According to Ministry of Interior Note (Urgent) No. 0810.3/6247 dated November 3, 2017 local community and village meetings should allow public participation. In case the public participation is less than 20 percent, the Local Administrative Organization shall hold the local community meeting if public participation is more than 5 percent and a local community meeting at subdistrict level shall be held. In case the public participation is less than 20 percent, the Local Administrative Organization shall hold the meeting if the public participation is more than 3 percent.

It is impossible for the public to witness PAO's preparation for the provisions of the expenditure budget. There is no public participation in budgeting procedures as the major responsibility in preparing the provisions for the annual expenditure budget belongs to the staff and government units of LAOs. Then, in the budget approval process, it is the Provincial Administrative Organization Council who approves the budget. Despite the Council represents local people, it does not give room for people's vote for their preferred projects. Because of these facts, projects under PAOs are decided and approved by PAOs.

Budgets, upon completion of the drafted provisions, are submitted to the Provincial Administrative Organization Council for approval. Public participation is absent in this process. This study finds that each locality adopts different criteria to allocate or determine the budget [5][6]. First, prioritization is given to projects with urgency and potential damages to large population if they are not implemented. Thus, these projects are the first priority. Second budget allocation is based on conditions, necessities, size and population density of localities. Third, proportion of council member is the basis. This means the locality where many council members are from obtains the considerable budget allocation. Fourth, the priorities of the development strategy of PAO, partly determines budget allocation. Localities with projects that align with the development plan are more likely receive their desired budget. As for localities without projects that do not respond to the strategies, they are more likely to obtain smaller budgets. 
Finally, there is a lack of financial support for people to participate in drafting the local development plan. Public participation is slight, as seen in meetings including committees' meetings, development plan meetings and even in local community meetings where public representatives are selected. This is mainly due to transportation costs, such as fuel, that prevent the public from physically attending meetings. Some participants pay nearly 200 baht for one round trip to a meeting [7]. This cost is not included by the Ministry of Interior Regulation on the Formulation of Development Plan of Local Administrative Organization, B.E. 2548 and so as in the Amendment version. None of them mention an allowance, honorarium, or transportation allowance for the representative from the public.

\section{Conclusion}

In Thailand, the public can participate in the budgeting process, but only by formulating local development plans. They are barred from other budgeting procedures including determining the provisions for the expenditure budget, prioritizing and selecting projects. These plans would not be feasible without the budgeting procedures. Drafting the provisions of expenditure budget is the procedure that determines the plans' feasibility and budget allocation. In this budgeting procedure, the decision makers are PAOs' executives and the Provincial Administrative Organization Council.

If people are to participate further in budgetary decision-making, there needs to be a policy shift at national level. Hence, if the relevant laws provide that participatory budgeting shall be compulsory, people can participate in decision making. The votes in the referendum are the agreement that binds local governments. Local meetings can be organized by the Local Council or the Mayor or one fourth of the eligible voters. Their meetings may place emphasis on diversified local issues, maybe health and environment. Decision would be finalized if over half of eligible voters present in the meeting and the majority of participants vote in favor to the projects. In addition, pattern of participatory may that a form suitable to each area. Examples include direct decisions about public matters or political issues or in the form of a third-party intermediary intermediation.

\section{References}

[1] J.B. Justice \& C. Dülger (2009). Fiscal Transparency and Authentic Citizen Participation in Public Budgeting: The Role of Third-party Intermediation. Journal of Public Budgeting, Accounting \& Financial Management, 21 (2), 254-288,2009.
[2] Local Administrative Reformation Committee, National Reform Council. List of opinions and suggestions on the draft constitution of the Local ,2015.

[3] A. Shah. Overview. In Shah A.(Ed)., Participatory Budgeting. pp. 1-20. Washington, DC: The Worldbank, 2007.

[4] B.Wampler. A Guide to Participatory Budgeting. In Shah A.(Ed)., Participatory Budgeting. pp. 2153. Washington, DC: The World bank, 2007.

[5] B. Sri-on. Director of Plan and Budgeting, Yasothon Provincial Administrative Organization. Interview on May 24, 2019.

[6] C. Somthep. Chief of Budget Division, Ubon Ratchathani Provincial Administrative Organization. Interview on June 26, 2019.

[7] S. Sena. Plan and Budgeting Division, Ubon Ratchathani Provincial Administrative Organization. Interview on June 26, 2019. 